\section{Land Access, Livelihood Diversification and Migration of Rural Youth in Sri Lanka}

Sri Lanka Journal of Economic Research Vol. 07(1): pp 47-74

Sri Lanka Forum of University

Economists

ISSN: 2345-9913

W.G.R.L. Samaraweera ${ }^{l}$, R.A.P.I.S. Dharmadasa ${ }^{l}$, J. Weerahewa ${ }^{2}$, P.H.T. Kumara ${ }^{3}$ and P.M.M. Fernando ${ }^{l}$

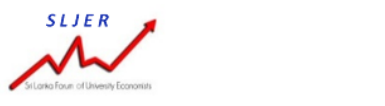

\begin{abstract}
Rural livelihood diversification and youth migration have potential impacts on Sri Lankan agricultural sector. Therefore, this study was designed to assess the impact of land access on rural youths' choice of livelihood and their choice of migration. A nationally representative sample of rural youth was isolated and a multinomial logit model under random utility framework was estimated to assess the livelihood diversification. A probit model of migration outcome was estimated to assess the rural youth's choice of migration in lieu of land access. Results revealed that land access is strongly associated with the livelihood choices of agriculture and urban salaried employment of rural youth. Being a female youth makes the choice of livelihood less likely to be in agriculture. Education acts as an upward driver in choosing urban salaried employment while educated youth tend not to choose agriculture. The tendency to migrate reduces with increased access to land. Therefore, land access is a crucial factor for rural youth to choose agricultural livelihoods alongside rural youth not to be migrated.
\end{abstract}

Keywords: Employment choice of rural youth, Farmland availability, Non-farm employment, Sustainable agriculture, Youth migration

\footnotetext{
${ }^{1}$ Department of Export Agriculture, Uva Wellassa University, Sri Lanka.

${ }^{2}$ Department of Agricultural Economics and Business Management, University of Peradeniya, Sri Lanka.

${ }^{3}$ Department of Public Administration, Uva Wellassa University, Sri Lanka.
} 


\section{Introduction}

\section{Background of the Study}

Rural livelihood diversification has driven the rural farmers to depend on a portfolio of income sources rather than relying on agriculture as their sole survival strategy (Weerahewa, 2004, Vries, 1993, Morrison, 1980). Rural youth exhibit livelihood diversification by migrating from farming into several other categories of employment such as off-farm wage employment, off-farm self-employment and urban-salaried employment. In addition, rural land holdings and access to arable lands decline over time (Mapa et al, 2002). Lewis (1954) elaborates labor migration from rural to urban sector is theoretically inevitable since structural transformation befall with economic development. However, with respect to domestic economic performance and labor market structures, the tradeoff between agricultural labor and other sectors is immense.

\section{Problem Statement}

The extent of youth participation in an economy determines the overall sociocultural, environmental and economic sustainability of a particular nation (UN, 2016). Despite the fact, high unemployment prevails among Sri Lankan Youth, in 2015, 20.8\% of the total youth in Sri Lanka was unemployed (DCS, 2016).

It is evident that the structural transformation which transformed the conventional agricultural economy towards more service-dominant economy has diversified the rural livelihoods. As a result, the labor migration occurred from farming to other sectors drastically reduced the domestic agricultural output (Central Bank of Sri Lanka, 2016). As per the Department of Census and Statistics (DCS), a significant reduction of domestic agricultural labor force (13\%) has been observed during the period from 2008 to 2016 (DCS, 2016). Hitihamu et al, (2013) further support the fact as in 1992, 42.2\% of the total employed population comprised of agricultural labor whereas in 2010, it has been reduced to $32.7 \%$.

Several categories of livelihood choices have been identified in the process of livelihood diversification. According to Vries (1993) off-farm wage employment, off-farm selfemployment and urban salaried employment are the most dominant categories. Some scholars argue that livelihood diversification is necessary for economic development and often beneficial. However, there is a constant debate on the impact of livelihood diversification on certain adversely affected sectors similar to agriculture. Therefore, it is necessary to focus on the factors which influence livelihood diversification in order to formulate effective policies for efficient resource management in those adversely affected sectors.

In this endeavor the livelihood choices of rural youth are vital (UN, 2016) because of induvial choices in aggregation exhibit a significant impact on a nation's labor supply. 
Individual-level choice making is a constrained optimization problem where an individual tries to maximize his/her utility and the impacts of such decisions are reflected predominantly under two stages. The immediate impacts of particular choices are observed at the micro-level and subsequent impacts are reflected at the macro-level. Thus, the following research question has been raised. According to the Sri Lankan land policy and current socio-economic status, does the land access have a significant impact on livelihood decisions of rural youth? This study provides a comprehensive technical analysis to reveal evidence in answering the above question.

Youth migration in the domestic context was marginal until recent years due to the structural differences between the rural and urban sectors. Majority of migrant youth from rural sector is being employed in the urban informal sector (Hettige and Mayer, 2002). However, benefits gained from international migration are often higher when compared to the migration within the country. Thus, youth outmigration in search of foreign employment is prominently observed and often encouraged by the government policies as a remedy to overcome the BOP crisis (Gunatlilaka et al, 2010). Nevertheless, the government imposed strict regulations on under-aged migration in 2009. Despite the fact, youth outmigration exhibits a 10.85 percent increase from 2009 to 2017 (Sri Lanka Bureau of Foreign Employment, 2017). Scholars have found that high poverty levels and the intention of enhanced survivability have driven youth migration and remittances as a key poverty elevation factor (Dharmadasa, Weerahewa and Samaratunga, 2017; Gamburd, 2005; Kottegoda, 2004).

In a country where the arable land extent is limited and lands are privately owned (Land Reform act 297, 1972) having farmland might be a significant factor for the rural youth to choose an agricultural livelihood among the rest of the main sources of income. Out of 6.55 million ha of land area, only 50\% is arable in Sri Lanka. Census on land use emphasizes the heavy pressure on agricultural land use in Sri Lanka. The per capita arable land area for an estimated population of 18 million is 0.15 ha (Mapa et al, 2002). In 2015 the arable land area available per person was approximately 0.062ha (World Bank, 2018). Severe land access constraints have led the rural farmers in other countries to lease or hire the land, sharecrop or find a landowner who will lend lands free of charge for farming (Marzano, 2002). Therefore, the study raised another research question which is "whether the land access is an important determinant of livelihood choices of rural youth?"

\section{Objectives}

\section{Main Objective}

In light of the above background, the study estimates whether the land access influences the livelihood diversification among youths who resides in the rural sector where individuals move off from farming. 


\section{Specific Objectives}

- To examine whether land access influence the livelihood choice of being agriculture among rural youth in Sri Lanka.

- To inspect the other factors that influences the livelihood choices of the rural youth in Sri Lanka.

- To examine whether the land access is a determinant of choice of migration among rural youth in Sri Lanka.

\section{Literature Review}

\section{Status of Youth in Sri Lanka}

The United Nations define individuals between the age 14-25 are as youth (UN, 1985). According to the National Youth Policy of Sri Lanka, both married and unmarried personnel who are aged between 15-29 are considered as youth (National Youth Policy, 2014). The estimated youth population in 2011 has been recorded as 4.4 million or $22 \%$ of the total population of Sri Lanka (De Silva, 2012). Census conducted by government agencies convey that the labor force is getting more educated over the years (DCS, 2016). However, the main employment strategy for youth remains in the informal sector (Gunatilaka et al, 2010). Since the mid-1990s, the importance of the informal sector as a source of employment has increased despite the higher rate of unemployment. Therefore, the Government of Sri Lanka launched the National Youth Policy in 2014 designed to address widespread youth unemployment through youth empowerment, gender inclusivity and entrepreneurship (OUSL, 2016). The Youth Development Division within the Ministry of Youth Affairs and Skill Development is responsible for youth affairs and is the "main institution" responsible for implementing the national youth policy (2014). Nevertheless, the literature on youth, agricultural livelihoods and land access is limited. Moreover, evidence on livelihood diversification does not specifically emphasize youth livelihood choices even at the national level.

\section{Drivers of Livelihood Diversification in Rural Areas}

Livelihood diversification is the "process by which rural families construct a diverse portfolio of activities and social support capabilities in order to survive and to improve their standards of living" (Ellis, 1998).

Lipton and Maxwell (1992) argue that a livelihood is not just the income and there is more to it namely; social institutions such as family, kin, the compound, village and etc., gender relations and property rights. And these factors often influence an individual's choice of livelihood between mutually exclusive livelihood choices (Berry, 1997; 1989; Bryceson, 1996; Hart, 1994). 
According to the farm household economic model, a household is a single decisionmaking unit which maximizes its welfare with respect to a variety of income-earning opportunities and a set of resource constraints (Nakajima, 2012; 1969; Ellis, 1993; Singh et al, 1986; Hymer and Resnick, 1969). Three dominant categories of income have been identified with regards to income diversification namely; farm income, nonfarm income and off-farm income (Saith, 1992). The author further argues that income diversification as the initial stage of livelihood diversification. Marzano (2002) identifies four dominant categories of livelihood choices in the rural sector namely; agriculture, off-farm wage employment, off-farm self-employment and urban salaried employment. More importantly, assets ownership is a vital determinant of livelihood diversification. Therefore, households with poor resources are vulnerable not to diversify due to the fact that imposed entry barrier resulted from the lack of resource possessions (Khatun and Roy, 2012). They also counter-argue that the asset possession is necessary for diversification, however, does not emphasize on land access. As shown in the empirical studies there are various determinants which drive the livelihood choices in the rural sector, therefore, focusing on a clearly separable single factor will ignore many underlying determinants which are inseparable in nature (Berry, 1989; 1997).

\section{Livelihood Diversification and Migration}

Literature on migration provides interesting insight into some of the determinants of livelihood diversification. Migration decisions have been considered as individual choices and as well as intertemporal family contracts (Stark and Lucas, 1988; Stark and Bloom, 1985; Stark, 1980; Harris and Todaro, 1970; Todaro, 1969). The individual choice of migration is determined by the income differentials adjusted for the job search probabilities (Larson and Mundlak, 2003; 2002; Bigsten, 1996). The risk spreading and imperfections of capital markets in rural sector are the prominent determinants of migration according to the explanation given for intertemporal family contracts (Collier, 1989; Katz and Stark, 1986; Stark and Levhari, 1982; Stark, 1980).

Both push and pull factors of migration are discussed in the migration literature. Therefore the, most prominent pull factors are the income differentials, seasonality, risk, market failures, erosion of assets. In addition, disasters leading to livelihood collapse are the push factors of migration.

\section{Land Access}

Julian Quan (2006) broadly defines land access as the processes by which people individually or collectively gain rights and opportunities to occupy and utilize land (primarily for productive purposes but also other economic and social purposes) on a temporary or permanent basis. The author further elaborates the forms of land access as, participation in both formal and informal markets, land access through kinship and 
social networks, the transmission of land rights through inheritance and within families and land allocation by the state and other authorities (Quan, 2006). Land tenure is another form of land access which can be classified into four major categories. The first category is private land ownership where the land rights are bestowed to a private party. Secondly, is the communal ownership where each member of the community has the right to use the land held by the community. Thirdly, the open access to land, in this form of access specific rights are not assigned to anyone and no-one can be excluded. Finally, land ownership by the state, where the property rights are assigned to certain governmental bodies or authorities (FAO, 2004).

Land statistics in Sri Lanka compile information predominantly with respect to the land ownership. As per these figures, the total land extent of Sri Lanka is limited to 6.55 million hectares, whereas only about $50 \%$ of the land is arable (COHRE, 2007) due to the factors such as unsuitable terrain, inland water bodies and forest reservations (Mapa et al, 2002). Therefore, conducting studies on land access is a timely requirement.

\section{Random Utility Framework}

Mankiw (2014) describes utility as a person's subjective measure of wellbeing or satisfaction. Arnold (2011) illustrates utility in relation to the satisfaction an individual receives from a good. Thus, utility of a consumer is a measure of satisfaction (Krugman, 2015). Scholars further emphasize that an individual's choices are determined by the level of utility gained and individuals always try to maximize their utility (Krugman, 2015; Mankiw, 2014; Arnold, 2011).

Therefore, the random utility framework is employed in economics for a better understanding of individual behavior, improve the accuracy of forecasts and to test the validity of simpler models. The basis for the random utility framework is the notion that an individual drives utility by choosing an alternative among a set of mutually exclusive choices (Walker and Akiwa, 2002). Random Utility Models (RUM) include flexible disturbances, latent variables, latent classes and combination of revealed preferences and stated preferences (Cai, 2013; Guimaraes, Figueiredo, and Woodward, 2004). Latent variables are the variables that are unobservable in nature. In order to include these variables, some observable variables are taken as proxies to the corresponding latent variable. Latent variables can be continuous or discrete in nature (Cai, 2013). 
Table 1: Classes of latent variable models

\begin{tabular}{|c|c|c|c|}
\hline & & \multicolumn{2}{|c|}{ Latent variable } \\
\hline \multirow{5}{*}{ 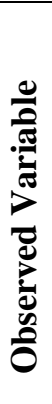 } & & Continuous & Discrete \\
\hline & \multirow{2}{*}{ Continuous } & Factor Analysis/Structural & Latent Profile Analysis \\
\hline & & Equation Modeling & Mixture Modeling \\
\hline & \multirow{2}{*}{ Discrete } & Item Response Theory & Latent Class Analysis \\
\hline & & Latent Trait Analysis & \\
\hline
\end{tabular}

Source: Cai, (2013)

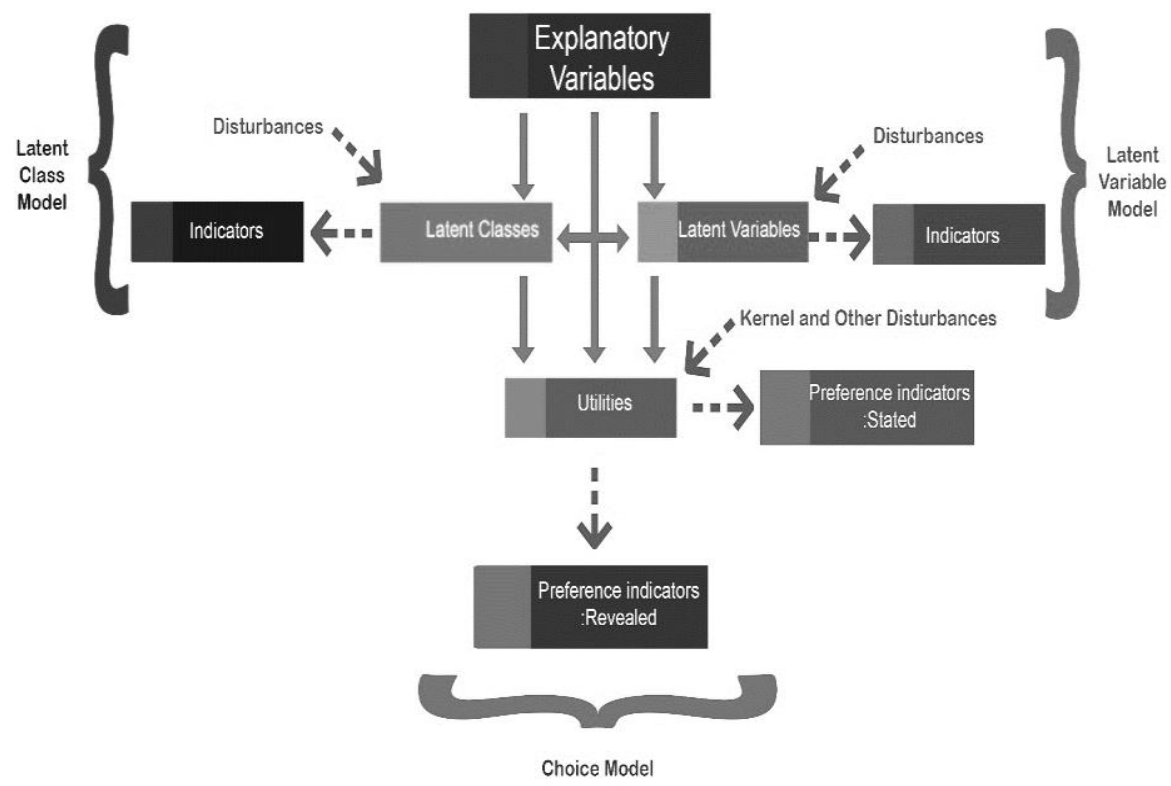

Figure 1: Generalized random utility model

Source: Walker \& Ben-Akiva, (2002) Generalized random utility model.

\section{Methodology}

\section{Data}

Descriptive and inferential statistics were estimated utilizing the secondary data, primarily collected by the Department of Census and Statistics (DCS) compiled under the Household Income and Expenditure Survey (HIES) - 2016. HIES is a nationally representative data set. Sampling technique employed for the survey is two-stage 
stratified sampling. Data regarding nine dimensions of both individuals and households in the country, covering demography, school education, health, food and non-food expenditure, income, inventory of durable goods, access to facilities in the area and debts of the households, housing information and agricultural land access along with land holdings and livestock holdings were gathered under HIES.

\section{Conceptual Framework}

\section{Livelihood Diversification and Migration Decisions of Rural Youth}

Individual choice-making was assessed via two models which were fundamentally developed based on the random utility framework. The first model estimated the individual and household level factors influencing rural youth's livelihood choices. A detailed description of the variables incorporated in both models is presented in the following sections. The second model was to assess the individual and household level factors influencing the rural youth's migration decision. Figure 2 illustrates the conceptual framework developed for the underlying study.

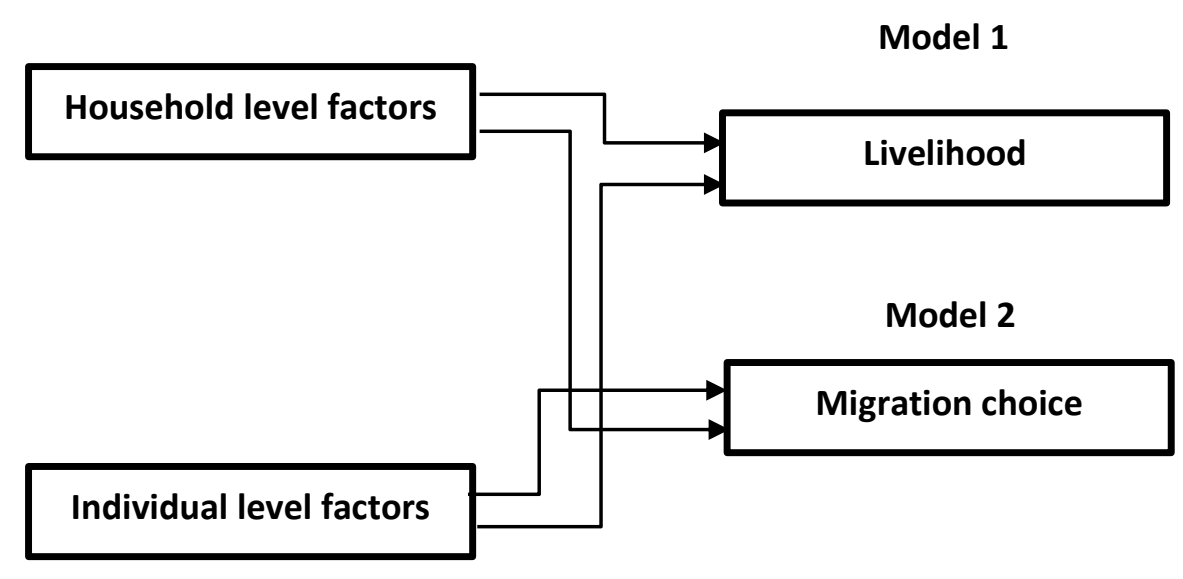

Figure 2: Conceptual framework

\section{Empirical Strategy}

Random utility framework models the decision maker's choice among a set of mutually exclusive alternatives. (Walker and Ben-akiwa, 2002). Livelihood choice of youth is a choice among many alternatives and an individual will choose the best alternative that maximizes his/ her utility in contrast to the remaining alternatives. Therefore, a multinomial logit model was estimated based on the generalized random utility model initially developed by Walker and Ben-Akiva, (2002) to model the livelihood choice decisions of the rural youths. $X$ is a vector that denotes factors that influence the 
livelihood choice of youth. Coefficients of these explanatory variables are different for each alternative. Both individual-level factors and household level factors are expected to influence the livelihood choice of rural youth. Thus, the response probabilities of the estimated multinomial logit model can be given as,

$$
\operatorname{pr}\left(y=\frac{\boldsymbol{j}}{x}\right)=\frac{\exp \left(\boldsymbol{X} \beta_{j}\right)}{\left(1+\sum_{j=1}^{5} \exp \left(\boldsymbol{X} \beta_{j}\right)\right)}, \quad j=1, \ldots, 5
$$

Where $\boldsymbol{j}$ denotes the alternative livelihood such that

Agriculture

Off-farm wage employment

Off-farm self-employment

Urban salaried employment

Unemployed

The model estimates the livelihood diversification under five distinct levels. Agriculture, off-farm wage employment, off-farm self-employment and urban salaried employment are the four prominent categories of livelihood choices available in the rural sector. Unemployed youth were included in the model to assess the impact of the explanatory variables on youth unemployment. Explanatory variables therefore comprised of both individual and household level factors (see table 2).

Table 2: Model variables

\begin{tabular}{ll}
\hline Individual level factors & Characteristics of youth \\
Age & Gender \\
Marital status & Ethnicity \\
& Whether the youth is a student \\
& Endowment of the youth \\
& Own human capital \\
& Education \\
& Land holdings \\
& Livestock holdings \\
& Age of the household head \\
& Education of the household head \\
Dousehold level factors & Demographics
\end{tabular}


In addition to these variables, district dummies were included to control the local variations in available opportunities and constraints. The main hypothesis tested was whether land access influences the livelihood choice of rural youth.

A probit model of migration outcome was estimated to analyze the factors influencing the migration decision of rural youth.

\section{Results and Discussion}

\section{Descriptive Statistics}

Table 3 exhibits the main overview of the isolated youth sample. The sample is consisted of 9,196 youths who were belonged to the rural sector. Accordingly, 52\% of the youth were female. School enrollment of the sample was high. $49.74 \%$ among male and $50.26 \%$ of females were enrolled in schools at least once in their lifetime. $37.18 \%$ of youths, were engaged in educational activities rather than engaging in economic activities. Again, there are more female students than male students.

Table 3: Main overview of rural youth

\begin{tabular}{lccc}
\hline & Male & Female & Total \\
\hline Sample Size & 4,412 & 4,784 & 9,196 \\
Percentage (\%) & 47.98 & 52.02 & 100 \\
\cline { 2 - 4 } & Percentage & & \\
\cline { 2 - 4 } Attended School at least once & 49.74 & 50.26 & 76.57 \\
Currently Student & 48.44 & 50.25 & 49.38 \\
Married & 6.53 & 20.67 & 13.89 \\
Involved in agriculture & 2.88 & 0.77 & 1.78 \\
Unemployed & 13.24 & 11.27 & 12.21 \\
Live with parents & 86.65 & 76.42 & 81.33 \\
\hline
\end{tabular}

Source: HIES 2016 - DCS

More than one-fourth of the young women were married with contrast to their male counterparts, Moreover, Youth engagement in agricultural activities exhibited as low as $1.78 \%$ of the total youth in the sample. A critical finding is that the overall youth enrollment in agriculture is less than $2 \%$. Female youth's engagement in agriculture is far less than male youth.

The data revealed the prevailing higher rate of unemployment among rural youths. Youth unemployment in the rural sector recorded as more than twelve per cent. Rural young males are more unemployed (13.24\%) than that of young females $(11.27 \%)$. 
Majority of the youth $(81.33 \%)$ in the sample live with parents and young males are more likely to live with parents rather than young females. As a custom, young women in the rural sector depart their parents' house after the marriage to live with their husbands.

According to the Food and Agricultural Organization (FAO), per person average agricultural land holdings in Sri Lanka is 0.5 ha. In light of that, the study results exhibit $95.54 \%$ of households in the urban sector, $63.73 \%$ of households in the rural sector and $84.89 \%$ households in the estate sector possess landholdings of an area equal or less than 0.5 acres (0.2 ha) or do not possess any kind of agricultural land holdings.

The mean farm size available for a household is 0.25 hectares $(0.63$ acres $)$ which sustain an average household size of 4 members. $72.47 \%$ of households in Sri Lanka possess agricultural land access less than or equal to 0.1 hectares and the percentage of households with agricultural land access less than or equal to 0.2 hectares is $75.47 \%$. Households in rural sector have larger farms when compared to urban and estate sector households. Majority of estate sector households cultivate very smaller farms. The study unravels that more than $70 \%$ households of the sample do not possess any agricultural landholdings. Estate sector households suffer severe agricultural land scarcity followed by urban and rural sector households. Nevertheless, despite the mean household size according to the analysis is approximately four, estate sector comprises of significantly larger households. These estate sector households possess more livestock assets with contrast to rural and urban sectors of Sri Lanka. Table 4 exhibits household lands ownership by sector.

Table 4: Agricultural land holdings by sector

\begin{tabular}{|l|c|c|c|c|}
\hline & $\begin{array}{c}\text { Urban } \\
\text { Sector }\end{array}$ & $\begin{array}{c}\text { Rural } \\
\text { Sector }\end{array}$ & $\begin{array}{c}\text { Estate } \\
\text { Sector }\end{array}$ & Total \\
\hline Avg. land holdings of a household (in acres) & 0.17 & 0.75 & 0.03 & 0.63 \\
\hline Households with no land holdings (\%) & 89.7 & 65.76 & 91 & 70.61 \\
\hline Households with land holdings $\leq 0.5$ acre (\%) & 95.54 & 74.64 & 98.07 & 78.94 \\
\hline Households with land holdings $\leq 1$ acre (\%) & 96.73 & 81.79 & 99.04 & 84.89 \\
\hline Households with land holdings $\leq 0.1$ ha (\%) & 93.81 & 67.08 & 94.64 & 72.47 \\
\hline Households with land holdings $\leq 0.2$ ha (\%) & 95.01 & 70.45 & 97.32 & 75.47 \\
\hline Household size (Mean) & 4.19 & 4.01 & 4.42 & 4.06 \\
\hline Average livestock holdings per household & 0.1 & 0.26 & 0.3 & 0.24 \\
\hline Number of observations & 3,427 & 19,390 & 933 & 21,750 \\
\hline
\end{tabular}

Source: HIES 2016 - DCS 


\section{Access to Land by Youth}

Census of Population and Housing (CPH) 2012 reports the total population of Sri Lanka as 20.4 million people with annual growth rate of $0.7 \%$.

In the same year, the share of the youth population to the total population is $23.2 \%$ (DCS, 2012). Majority of the country's population resides in the rural sector which is 77.4\%. (DCS, 2012). Thus, the majority of youth in Sri Lanka resides in the rural sector of the country.

Table 5: Access to agricultural lands by youth by sector

\begin{tabular}{l|c|c|c|c}
\hline & Urban Sector & Rural Sector & Estate Sector & Total \\
\hline $\begin{array}{l}\text { Number of youths } \\
\text { Average land access } \\
\text { by youth (acres) }\end{array}$ & 2,026 & 9,196 & 513 & 11,735 \\
$\begin{array}{l}\text { Average land access } \\
\text { by youth (ha) }\end{array}$ & 0.2 & 0.84 & 0.06 & 0.68 \\
\hline
\end{tabular}

Source: HIES 2016 - DCS

For a small island, Sri Lanka is densely populated within a land area of 6,561,000 in hectares $\left(65,610 \mathrm{~km}^{2}\right)$. According to the World Bank (2018) the arable land extent of Sri Lanka in 2015 was 1,300,000 hectares. Nevertheless, there is no official record of youth land holdings in Sri Lanka at present. Table 5 exhibits the average land access for the youth in each sector. Land access by youth is on average is 0.28 hectares which is not nearly an acre. Access to arable lands by rural sector youth is greater than the youth in other sectors and youth in the estate sector exhibit the lowest land access.

\section{Present Educational Status of Rural Youth by Gender}

Table 6 exhibits the present educational status of rural youth in the sample. $49.8 \%$ of rural sector youths were not engaged in any educational activity. $37.9 \%$ of youths attend to schools. Youth engagement in higher educational activities such as universities is extremely low (1.46\%). However, female enrollment in universities is two times greater than young males. 
Table 6: Present educational status of rural youth by gender

Gender

\begin{tabular}{lccc}
\hline Current Educational status & Male & Female & Total \\
\hline School & 37.56 & 38.15 & 37.9 \\
University & 0.93 & 1.94 & 1.46 \\
Other educational institutions & 4.53 & 5.52 & 5.05 \\
Vocational / Technical & 3.74 & 2.65 & 3.18 \\
Pending results G.C.E. & 2.61 & 2.8 & 2.71 \\
Do not attend & 50.63 & 48.93 & 49.8 \\
\hline
\end{tabular}

Source: HIES 2016 - DCS

$5.05 \%$ of rural youths were enrolled in other education activities. Which indicates that they are developing their human capital through educational activities in addition to school education. $3.18 \%$ of youths follow vocational and technical education in the sample which might influence the rural youth to choose other livelihood strategies apart from agricultural livelihood. $2.71 \%$ of youths in the rural sample were expecting the G.C.E. examination results. The ones who do not attend school belonged to all ages of youth (15 years- 24 years).

\section{Choice of Livelihood / Occupation}

Table 7 differentiates the economically active youth from economically inactive youth in all sectors. More than one-fourth of the youth belonged to all three sectors were economically inactive.

Table 7: Economically active and inactive youth by sector

\begin{tabular}{|c|c|c|c|c|}
\hline & \multicolumn{4}{|c|}{ Sector } \\
\hline & Urban & Rural & Estate & Total \\
\hline & \multicolumn{4}{|c|}{ Percentage (\%) } \\
\hline Economically active & 26.65 & 23.63 & 32.94 & 24.56 \\
\hline Economically inactive & 73.35 & 76.37 & 67.06 & 75.44 \\
\hline
\end{tabular}

Source: HIES 2016 - DCS

Table 8 exhibits the main activities of the rural youth. $23.19 \%$ of the rural sector youths were engaged in economic activities; however, it is less than in the urban sector. In addition, a significant number of rural youths (12.21\%) were unemployed whereas 
estimated youth unemployment in the urban sector was $9.38 \%$. Thus, it confirmed the prevailing higher unemployment among rural youth.

Table 8: Main activity engaged by rural youth

\begin{tabular}{lcc}
\hline Main activity & Frequency & Percentage (\%) \\
\hline Engaged in economic activities & 2,133 & 23.19 \\
Seeking for available work & 1,123 & 12.21 \\
Student & 4,541 & 49.38 \\
Engaged in household activities & 1,119 & 12.17 \\
Unable to work (disabled) & 95 & 1.03 \\
Other & 185 & 2.01 \\
Total & 9,196 & 100 \\
\hline
\end{tabular}

Source: HIES 2016 - DCS

Majority of rural youth were engaged in educational activities rather than economic activities. Moreover, labor laws in Sri Lanka have fixed the minimum working age as 14 years of age, there were more students mainly due to the characteristics of the existing educational system. A significant percentage of rural youths are engaged in household activities which is greater than in the urban sector.

Table 9: Main activity engaged by rural youth by gender.

\begin{tabular}{lllll}
\hline Main activity & & \multicolumn{3}{c}{ Gender } \\
\hline Engaged in economic activities & Frequency & 1,480 & 653 & 2,133 \\
& $\%$ & 33.54 & 13.65 & 23.19 \\
\hline Seeking for available work & Frequency & 584 & 539 & 1,123 \\
& $\%$ & 13.24 & 11.27 & 12.21 \\
\hline Student & Frequency & 2,137 & 2,404 & 4,541 \\
& $\%$ & 48.44 & 50.25 & 49.38 \\
\hline Engaged in household activities & Frequency & 56 & 1,063 & 1,119 \\
& $\%$ & 1.27 & 22.22 & 12.17 \\
\hline Unable to work (disabled) & Frequency & 61 & 34 & 95 \\
& $\%$ & 1.38 & 0.71 & 1.03 \\
\hline Other & Frequency & 94 & 91 & 185 \\
& $\%$ & 2.13 & 1.9 & 2.01 \\
\hline
\end{tabular}

Source: HIES 2016 
Table 9 exhibits the gender-wise proportions in each activity of rural youth. Rural young males are more economically active than young females. Male engagement in economic activities is 2.5 times greater than female engagement. Moreover, the intensity for young males to seek for available work is higher when compared to young females. Rural young males are more burdened with responsibilities in addition to their survival. Thus, they are more economically active than females. Therefore, eventually, they seek for jobs in contrast to their female counterparts. Nevertheless, females are committed to household activities instead of being employed. $22.22 \%$ of female youths are engaged in the household activities and only $1.27 \%$ male youths belong to the same category. Female magnitude is 17 times greater than the male magnitude in this scenario. This phenomenon has several socio-economic and cultural influences which are beyond the objectives of this study.

The rural youth sample consisted of more female students than male students, a situation similarly observed in the urban sector.

Table 10 exhibits the employment choices of rural youth. 65.55\% of them are economically inactive due to their educational activities and household activities. The sample consisted of more economically inactive female youth than male youth. Furthermore, only $1.73 \%$ of rural youths have chosen agriculture as their livelihood strategy. Thus, this is a social change which needs to be assessed to counter the potential shortcomings and its negative impacts on the economy. Male engagement in agriculture is greater than the females however; overall engagement is very low even though this is the rural sector.

Table 10: Economic activities / Livelihood choices of rural youth

\begin{tabular}{lccc}
\hline & \multicolumn{3}{c}{ Gender } \\
\hline & Male & Female & Total \\
\hline Other (Economically inactive) & \multicolumn{3}{c}{ Percentage (\%) } \\
\cline { 2 - 4 } Agriculture & 55.28 & 75.02 & 65.55 \\
Off-farm wage employment & 2.81 & 0.73 & 1.73 \\
Off-farm self-employment & 18.52 & 6.02 & 12.02 \\
Urban-salaried employment & 1.68 & 1.15 & 1.4 \\
Unemployed & 8.48 & 5.81 & 7.09 \\
\hline
\end{tabular}

Source: HIES 2016

Off farm-wage employment depicts as the most preferred livelihood choice among rural youth which is greater than as observed in the urban sector. Male youth's choice of offfarm wage employment is two times greater than the female youth. $7.09 \%$ of youths in 
the sample were engaged in the urban salaried employment which is less when compared to the urban sector. This may be due to the availability of a lesser number of formal employment and human capital development opportunities in the rural sector than in the urban sector. Despite the fact, it is still 4 times greater than the rural youth's choice of agriculture as a livelihood.

Off-farm self-employment among rural youth is less than $1.40 \%$. A possible cause can be the low risk-bearing ability of rural youth. The socio-economic, cultural and demographic conditions exist in the rural sector might have influenced the rural youth not to initiate their own small, medium or large-scale business startups. The startup wealth and capital required for establishing entrepreneurial ventures may be lacking at household-level thus; the youth may not have access to the required capital to initiate their startups. On the other hand, characteristics of the head of the household might also have impacts on the prevailing situation. Most of the conventional household heads may not want their youth household members to engage in self-employment due to the risk associated with such livelihood strategies. Therefore, in many cases, they influence the youth to choose urban salaried employment where decent salaries are being paid, with an expectation that it would uplift the living standards of the household and its young members. Youth may not want to bear the risk of new startups due to their intention of securing a stable form of livelihood and cash flow associated with the least possible risks. Therefore, they tend to choose urban salaried employment as their livelihood. Even though if this is the case, table 10 exhibits that $12.21 \%$ of rural youth are unemployed. Then why haven't they chosen agriculture as their livelihood choice which was prominent in the rural sector? Is it possible that this is due to the lack of land access for rural youth? Our inferential statistics delivered promising results.

\section{Inferential Statistics}

\section{Livelihood choice of rural youth}

A multinomial logit model was estimated to assess the correlations, the directions of relationships and their magnitudes, between the individual and household characteristics and livelihood choices. The relative returns and preference for agricultural and nonagricultural livelihoods were expected to be influenced by these individual and household level characteristics. Since the dependent variable is categorical, qualitative variable regression technique can be viewed as the most appropriate statistical technique for the estimation. Ordinal and multinomial regression models fall under qualitative variable models. However, the dependent variable of the particular model consisted of more than two outcomes and the levels have no natural or any kind of order. Thus, the use of ordinal logistic estimation was found inappropriate which left the multinomial logistic regression model as an ideal model for this analysis. Additional variables like regional dummies were incorporated in the model to eliminate the differences in infrastructure, information, agroecological and climatic conditions. These variables 
were also included for the assessment of whether the livelihood choice alters from place to place as well. Ethnicity dummies were incorporated to assess whether ethnic minorities are discriminated when choosing agriculture as their livelihood. The model was estimated considering the youth who have chosen agricultural livelihoods as the reference category in order to estimate the factors affecting the youth's choice of other livelihood strategies except for agriculture. Thereafter, the average marginal effects of covariates on the probability of choosing agriculture as a livelihood strategy was estimated to check the influences of these variables towards the probability of choosing agriculture as livelihoods. Log-likelihood coefficients are calculated and explained relative to the base outcome. 3,168 youths who were economically active were isolated out of the total 9,196 youths in the rural sector for the estimation of this model. The model is significant under $1 \%$ significant level.

Table 11: Multinomial models of determinants of livelihood choice by female and male youth in rural sector of Sri Lanka

\begin{tabular}{lr}
\hline Number of observations & 3168 \\
Wald chi2(105) & 820.16 \\
Prob > chi2 & 0.0000 \\
Pseudo R2 & 0.1292 \\
Log pseudolikelihood & -897218.6 \\
\hline
\end{tabular}

\begin{tabular}{|c|c|c|c|c|}
\hline Variables & $\begin{array}{l}\text { Off-farm } \\
\text { wage } \\
\text { employment }\end{array}$ & $\begin{array}{l}\text { Off-farm } \\
\text { self- } \\
\text { employment }\end{array}$ & $\begin{array}{l}\text { Urban } \\
\text { salaried } \\
\text { employment }\end{array}$ & Unemployed \\
\hline $\begin{array}{l}\text { Agricultural land access } \\
\text { (ha) }\end{array}$ & $-0.2406^{* * *}$ & -0.0834 & $-0.4169^{* * *}$ & $-0.2309^{* * *}$ \\
\hline Age of the youth & -0.0643 & -0.0145 & 0.0076 & $-0.2675^{* * *}$ \\
\hline Gender & 0.1296 & $0.9651^{* * *}$ & $0.5560^{* * * *}$ & $0.9815^{* * *}$ \\
\hline Education (years) & -0.0160 & -0.0426 & $0.4538 * * *$ & $0.3375^{\text {*** }}$ \\
\hline Livestock holdings & $-0.1866^{* * *}$ & $-0.3789 * * *$ & $-0.2829 * * *$ & $-0.3277^{* * *}$ \\
\hline $\begin{array}{l}\text { Age of the household } \\
\text { head }\end{array}$ & -0.0013 & -0.0121 & 0.0048 & 0.0157 \\
\hline $\begin{array}{l}\text { Education of household } \\
\text { head }\end{array}$ & $-0.0529 *$ & -0.0537 & 0.0128 & 0.0023 \\
\hline Married & -0.1424 & -0.3004 & $-0.4455^{*}$ & $-1.3737^{* * *}$ \\
\hline
\end{tabular}


Sri Lanka Journal of Economic Research Volume 07(1) 2019

Ethnicity-Tamil

$-0.1890$

$-0.8389$

$-0.4264$

$-0.5637$

Ethnicity-Sri Lankan

Moor

0.6159

$0.9267 * *$

$1.1021 * * *$

$0.7736^{\text {** }}$

Kandy

$-2.1355 * * *$

$-2.3393 * * *$

$-2.0464 * * *$

$-1.3787^{* *}$

Southern

$-1.0647^{*}$

$-1.4575^{* *}$

$-1.5781 * * *$

$-0.3711$

Northern

$-1.4791^{* *}$

$-1.9391 * *$

$-1.2827 *$

$-0.1304$

Eastern

$-2.1221 * * *$

$-2.6940 * * *$

$-2.2048 * * *$

North Western

$-2.1103 * * *$

$-2.1260 * * *$

$-2.1544 * * *$

$-1.8402^{* * * *}$

North Central

$-2.6374 * * *$

$-2.7985^{* * *}$

$-2.2109 * * *$

$-1.7228^{* * *}$

Uva

$-3.0672 * * *$

$-4.3452 * * *$

$-3.8302 * * *$

$-2.2852^{* * *}$

Sabaragamuwa

$-1.1445^{*}$

$-1.4125^{* *}$

$-1.8455^{* * * *}$

$-0.6296$

Constant

$5.9612 * * *$

$3.6792 * *$

$-1.9330$

$4.3084^{\text {**** }}$

***Significant at $1 \%, * *$ Significant at $5 \%, *$ Significant at $10 \%$

\section{Source: Authors' estimations}

The results of the multinomial logistic regression model unfold agricultural land access is strongly negatively associated with off-farm wage employment, urban salaried employment and unemployment. When the per capita agricultural land access is increased by 1 hectare the likelihood of rural young men and women of choosing offfarm wage employment, urban salaried employment decreases and along with that the likelihood the rural youth to be unemployed also shows a decline as reflected by the negative coefficients of the multinomial logit model. In other words, an increase in agricultural land access decreases the likelihood of rural youth to choose livelihoods outside agriculture. Therefore, it is evident that an important factor which has driven the rural youth away from agriculture is the lack of land access. As exhibited in Table 12 the average marginal effect of changing the covariates on the probability of choosing agriculture as a livelihood increase when the agricultural land access is increased. In other words, the reduction of agricultural land access declines the probability of rural youth to choose agriculture as a livelihood. Thus, the youth who belong to land poor households are less likely to choose agriculture as their livelihood.

The results also revealed that there is an inverse relationship between the age of the youth and the probability of being unemployed. As the youth matures, they are forced to choose any livelihood strategy for their survival and the survival of the dependents. And the model discloses when the land access is inadequate, they have to choose another livelihood apart from agriculture due to the fact that land is a primary factor of production in agriculture. 
However, the relationship between choosing agriculture as the livelihood and age of the youth depicts, as the rural young men mature there is a possibility for them to choose agriculture as the desired livelihood if there is adequate land access. Table 12 exhibits the average marginal effect of changing the covariates on the probability of rural youth choosing agriculture as a livelihood. It is evident that the female youth in the sector exhibits a lower probability to choose agriculture as their livelihood with contrast to their male counterparts. Thus, if the land access is increased, the probability of rural young men to choose agriculture as their livelihood increases.

Young women are more likely to choose off-farm self-employment and urban salaried employment as their choice of livelihood. Rural young women's most preferred livelihood choice is not agriculture instead, formal sector jobs where higher salaries are being paid, thus, they can maintain a higher social status. Educated youths exhibit a higher likelihood to choose urban salaried employment apart from choosing agricultural livelihoods. As the youth get more and more educated, the likelihood of choosing urban salaried employment rises while the likelihood of choosing agriculture as the livelihood declines. This is because, as the years of education increases the expectation of individuals to capture the highest return to education by engaging in formal sector jobs increases. An increase in education increases one's expectation of being successful in the urban sector (Todaro and Smith, 2015).

Livestock holdings by household reflect a highly significant, inverse relationship between livelihoods apart from agriculture and unemployment. Youth who belong to the households having fewer livestock holdings shows higher likelihoods of choosing offfarm wage employment, off-farm self-employment and urban salaried employment. On the other hand, when the livestock holding of a household is increased the probability of youth who belong to that household of choosing agricultural livelihood increases.

Youth who belong to the household where the head of the household is more educated are less likely to choose off-farm wage employment, which is the informal sector (Gunathilaka et al, 2010). When the household head is more educated, he or she expects their sons and daughters to have uplifted social and living standards. Therefore, the household head's influence is inevitable on the youth's livelihood choice apart from offfarm wage employment.

As the model depicts married youth are less likely to be unemployed. Responsibilities bought by marriage such that the need for provisioning the newly initiated family force rural youth to be engaged in any livelihood. Likelihood of married young men in the rural sector to choose agriculture as their livelihood increases with contrast to single youth. The land inheritance as gifts of marriage might have influenced the rural men's choice of livelihood to be agriculture due to the increased access to land.

Ethnicity dummies reveal the ethnic influence for the choice of livelihood. Sri Lanka is a country with vast ethnic diversity. The three major ethnic groups in the country are 
Sinhala, Tamil and Sri Lankan Moor. Sinhalese are the Ethnic majority of the country. Therefore, ethnic influence on the model is estimated with reference to the ethnic majority. There is no any statistically significant relationship between ethnic Tamils and their livelihood choices.

Table 12: Average marginal effects of covariates on the probability of choosing agriculture as a livelihood strategy

\begin{tabular}{|c|c|c|c|c|}
\hline Variables & $d y / d x$ & Standard error & $\mathbf{z}$ & $\mathbf{P}>\mathbf{Z}$ \\
\hline Agricultural land access (ha) & $0.0089 * * *$ & 0.0027 & 3.3200 & 0.00 \\
\hline Age of the youth & $0.0039 * * *$ & 0.0014 & 2.7100 & 0.01 \\
\hline Female youth & $-0.0176 * * *$ & 0.0058 & -3.0500 & 0.00 \\
\hline Education (years) & $-0.0068 * * *$ & 0.0025 & -2.7800 & 0.01 \\
\hline Livestock holdings & $0.0088 * * *$ & 0.0026 & 3.4100 & 0.00 \\
\hline Age of the household head & -0.0002 & 0.0003 & -0.5600 & 0.58 \\
\hline Education of household head & 0.0007 & 0.0011 & 0.6100 & 0.54 \\
\hline Married & $0.0215^{* *}$ & 0.0110 & 1.9600 & 0.05 \\
\hline Ethnicity-Tamil & 0.0146 & 0.0178 & 0.8200 & 0.41 \\
\hline Ethnicity-Sri Lankan Moor & $-0.0198 * * *$ & 0.0069 & -2.8700 & 0.00 \\
\hline Kandy & $0.1240 * *$ & 0.0617 & 2.0100 & 0.04 \\
\hline Southern & 0.0393 & 0.0331 & 1.1900 & 0.24 \\
\hline Northern & 0.0371 & 0.0436 & 0.8500 & 0.39 \\
\hline Eastern & 0.1019 & 0.0638 & 1.6000 & 0.11 \\
\hline North Western & $0.1397 * *$ & 0.0588 & 2.3800 & 0.02 \\
\hline North Central & $0.1791 * *$ & 0.0786 & 2.2800 & 0.02 \\
\hline Uva & $0.3057 * * *$ & 0.0997 & 3.0700 & 0.00 \\
\hline Sabaragamuwa & 0.0521 & 0.0418 & 1.2500 & 0.21 \\
\hline
\end{tabular}

$* * *$ Significant at $1 \%, * *$ Significant at $5 \%, *$ Significant at $10 \%$

Source: Authors' estimations

Nevertheless, young Sri Lankan Moors exhibit a lower tendency of choosing agricultural livelihoods whereas the tendency of choosing livelihoods apart from agriculture is significantly high. Regional dummies explain that the youth who reside in the regions where agriculture contributes to the GDP the most (FAO, 2018; Marambe et al, 2017) show a higher probability to choose agriculture as their livelihood choice if 
there is adequate land access. These are North Western, North Central and Uva regions. Youths who reside in these regions are less likely to choose other livelihood strategies apart from agriculture with increased land access. Therefore, lack of land access has left them with no other option but to choose any other livelihood but agriculture.

\section{Determinants of Migration}

Table 13 exhibits the results of the probit model of migration outcome. Agricultural land access shows an inverse relationship with the rural youth's choice of migration. Youth who belong to households with affluent agricultural land access shows fewer propensities to be migrated. In other words, youth who belong to households with poor land access exhibit higher propensity to be migrated. Thus, agricultural land access has a significant impact on rural youth's migration decision. Rural young women exhibit less probability of choosing to be migrated with contrast to their male counterparts. Youth who are currently students show less probability of choosing to be migrated. This is due to their attachment to the families and their expectation towards improved living standard through education which makes them not to be migrants until the completion of their education.

Education is a strong driver for youth migration in the rural sector. Educated youth show a higher probability of being migrated as shown by the positive coefficient which is highly statistically significant. Youth accumulate and develop their human capital with education making them be employed in the sectors where higher salaries are being paid. In Sri Lanka this is the urban sector. Skilled labor migration is another scenario which supports the above findings. Youth seek better opportunities abroad through education particularly with the hope of improved living standards (Todaro and Smith, 2015). Youth who belong to the households where the head of the household is more educated reflect less probability to be migrated whereas when the years of education of the head of the household is less the youth seek opportunities in the urban sector. This provides an upward pressure for the youth to be migrated (Fargues, 2017). Educated household heads may have jobs where decent salaries are being paid making their children not to be migrants. Married youth show a higher probability of being migrants when compared to single youth. To illustrate, married youth have more responsibilities than single youth thus they seek higher salaries and opportunities through internal or international migration (Ogawa et al, 2018; Palriwala, Uberoi and Thapan, 2008). Youth who belong to the ethnic group of Sri Lankan Moor exhibits a less probability to migrate with contrast to other ethnic groups in Sri Lanka. 
Sri Lanka Journal of Economic Research Volume 07(1) 2019

Table 13: Factors associated with rural household member migration decisions

\begin{tabular}{l|r} 
Number of observations & 9,196 \\
\hline Wald chi2(105) & 938.68 \\
\hline Prob > chi2 & 0.0000 \\
\hline Pseudo R2 & 0.2300 \\
\hline Log pseudolikelihood & $-814,357.79$
\end{tabular}

\begin{tabular}{|c|c|c|c|c|}
\hline Variables & Coefficient & Standard error & $\mathbf{z}$ & $\mathbf{P}>\mathbf{Z}$ \\
\hline Agricultural land access (ha) & $-0.11332 * * *$ & 0.0317163 & -3.57 & 0.00 \\
\hline Gender & $-0.68784 * * *$ & 0.0406731 & -16.91 & 0.00 \\
\hline Student & $-1.78487 * * *$ & 0.0703332 & -25.38 & 0.00 \\
\hline Education (years) & $0.104448 * * *$ & 0.0112733 & 9.27 & 0.00 \\
\hline Livestock holdings & 0.018814 & 0.0214799 & 0.88 & 0.38 \\
\hline Age of the household head & 0.001282 & 0.0017627 & 0.73 & 0.47 \\
\hline $\begin{array}{l}\text { Education of household head } \\
\text { (years) }\end{array}$ & $-0.04435^{* * *}$ & 0.0055856 & -7.94 & 0.00 \\
\hline Married & $0.123989 * * *$ & 0.0500592 & 2.48 & 0.01 \\
\hline Ethnicity - Tamil & 0.10815 & 0.0890774 & 1.21 & 0.23 \\
\hline Ethnicity - Sri Lankan Moor & $-0.18497 * * *$ & 0.0704879 & -2.62 & 0.01 \\
\hline Kandy & $-0.38262 * * *$ & 0.0715264 & -5.35 & 0.00 \\
\hline Southern & $-0.36533 * * *$ & 0.0620325 & -5.89 & 0.00 \\
\hline Northern & $-0.45823 * * *$ & 0.1058165 & -4.33 & 0.00 \\
\hline Eastern & $-0.39775^{* * *}$ & 0.0866376 & -4.59 & 0.00 \\
\hline North Western & $-0.18345^{* * *}$ & 0.0676029 & -2.71 & 0.01 \\
\hline North Central & $-0.35201 * * *$ & 0.0877537 & -4.01 & 0.00 \\
\hline Uva & $-0.6179 * * *$ & 0.0939581 & -6.58 & 0.00 \\
\hline Sabaragamuwa & $-0.27797 * * *$ & 0.0723053 & -3.84 & 0.00 \\
\hline Constant & $-0.78047 * * *$ & 0.1486475 & -5.25 & 0.00 \\
\hline
\end{tabular}

***Significant at 1\%,**Significant at 5\%, *Significant at 10\%

Source: Authors' estimations 


\section{Conclusions}

Sri Lanka's rural youth face severe agricultural land access constraints even though the constitution of Sri Lanka grants the right of private ownership and transfer of land to its citizens. Being an island nation with limited arable land extent, allocation of lands for agriculture is a critical policy issue with accelerated population growth. Land access is a crucial factor for rural youth in choosing agriculture as their livelihood choice. However, a preponderance of households in the rural sector does not possess any agricultural land access. In different circumstances arable lands available are not cultivated which is a visible indicator of lack of land access. Lack of land access to rural youth has diversified the traditional livelihood of the rural sector by being a driver for rural youth to look towards other livelihood options apart from agriculture. Only $1.73 \%$ of youths in the sample have chosen agriculture as their livelihood. As the results reveal, higher the agricultural land access higher the likelihood of rural youth to look towards agricultural livelihoods. Moreover, unemployment among rural young men and women prevails at a higher rate. Estimated models suggest an increase in land access will decrease the unemployment among rural sector youth. In addition, the education level has a significant impact on rural youth's livelihood decisions. Livestock holdings in the household level also influence the livelihood decision of the rural youth. Youth who belong to households with affiliate livestock holdings show higher probability to choose agriculture as their livelihoods with contrast to livestock poor households.

Majority of rural youth are economically inactive even though the minimum working age is defined as 14 years by the Sri Lankan labor laws. Many of them are students or engaged in household activities. Majority of youth who engaged in domestic activities are females. Promoting women entrepreneurship in domestic levels may incorporate their contribution to the economy.

Furthermore, agricultural land access significantly impacts on rural youth's migration decision. It is a crucial factor for rural youth not to be migrated. Possible increase in agricultural land access to rural youth reveals a tendency for them not to be migrants. Education level acts as an upward driver on the rural youth's decision of migration. Educated youth are highly likely to be migrated from the rural sector.

Increasing agricultural land access can be seen as a positive intervention for driving the productivity of rural youth. Therefore, government policy reformation should be focused on achieving this endeavor. Reallocation of uncultivated arable lands to rural youth and providing access to credit for acquiring agricultural land for youth would be credible suggestions which in turn would abate the prevailing higher rate of unemployment. Access to agricultural lands for rural youth is to be increased in order to ensure sustainable agriculture, sustainable production along with eradication of inequalities in the form of access to land and to abridge the adverse effects of outmigration of youth from the rural sector of Sri Lanka. 


\section{References}

Arnold, R. A. (2011). Principles of economics. South-Western, Cengage Learning.

Berry, S. (1989). Social institutions and access to resources. Africa, 59(1), 41-55.

Berry, S. (1997). Tomatoes, land and hearsay: property and history in Asante in the time of structural adjustment. World Development, 25(8), 1225-1241.

Bigsten, A. (1996). The circular migration of smallholders in Kenya. Journal of African Economies, 5(1), 1-20.

Bryceson, D.F., (1996). 'Deagrarianization and Rural Employment in SubSaharan Africa: A Sectoral Perspective', World Development, Vol.24, No.1, pp.97-111.

Butzer, R., Larson, D. F., and Mundlak, Y. (2002). Intersectoral migration in Venezuela. Economic Development and Cultural Change, 50(2), 227-248.

Butzer, R., Mundlak, Y., and Larson, D. (2003). Intersectoral migration in Southeast Asia: evidence from Indonesia, Thailand, and the Philippines. The World Bank.

Cai, L. (2013). Potential applications of latent variable modeling for the psychometrics of medical simulation. Military medicine, 178(suppl_10), 115-120.

Central Bank of Sri Lanka. (2016). Annual Report. Retrieved August 4, 2018, from Central Bank of Sri Lanka website: https://www.cbsl.gov.lk/sites/default/files/cbslweb_documents/publications/ann ual_report/2017/en/6_Chapter_02.pdf

Collier, P. (1989). Contractural Constraints on Labour Exchange in Rural Kenya. Int'l Lab. Rev., 128, 745 .

Damayanthi, M. N., de LW Samarasinhe, G. G., Bandara, M. A. C. S., Hitihamu, H. M. S. J. M., and Perera, S. (2013). Youth in Development: Sri Lanka. Hector Kobbekaduwa Agrarian Research and Training Institute.

DCS. (2011). All Sectors Index. Retrieved October 21, 2018, from Statistics.gov.lk website: http://www.statistics.gov.lk/agriculture/AllSectors/index.htm\#tb1A

Department of Census and Statistics. (2012). Census on Population and Housing. Retrieved from Census on Population and Housing website: http://www.statistics.gov.lk/PopHouSat/CPH2011/Pages/Activities/Reports/Fin alReport/FinalReport.pdf

Department of Census and Statistics. (2016a). Household Income and Expenditure Survey. In statistics.gov.lk. Retrieved from Department of Census and Statistics website:

http://www.statistics.gov.lk/HIES/HIES2016/HIES2016_FinalReport.pdf 
Department of Census and Statistics. (2016b). Labor Force Survey - Annual Report. In statistics.gov.lk (pp. 4-77). Retrieved from Department of Census and Statistics website:

http://www.statistics.gov.lk/samplesurvey/LFS_Annual\%20Report_2016.pdf

Dharmadasa, R. A. P. I. S., Weerahewa, J., and Samarathunga, P. A. (2018). Labor migration and impact of remittances on poverty and income inequality: evidence from estate sector of Sri Lanka. Tropical Agricultural Research, 30(1), 69-83.

De Silva, W. I. (2012). Sri Lankan Population Change and Demographic Bonus Challenges and Opportunities in the New Millennium.

Ellis, F. (1993). Peasant economics: Farm households in agrarian development (Vol. 23). Cambridge University Press.

Ellis, F. (1998). Household strategies and rural livelihood diversification. The journal of development studies, 35(1), 1-38.

Fargues, P. (2017). International migration and education: a web of mutual causation.

Food and Agricultural Organization. (2018). Country Gender Assessment of Agriculture and the Rural Sector in Sri Lanka. In Food and Agricultural Organization. Retrieved from Food and Agricultural Organization website: http://www.fao.org/3/ca1516en/CA1516EN.pdf

Gamburd, M. R. (2005). Lentils there, lentils here! Sri Lankan domestic labour in the Middle East. Marshall Cavendish Academic, Singapore.

Harris, J.R. and Todaro, M.P., 1970. Migration, unemployment and development: a two-sector analysis. The American economic review, 60(1), pp.126-142.

Hart, G. (1994). The dynamics of diversification in an Asian rice region. Development or deterioration, 47-71.

Hettige, S., and Mayer, M. (2002). Sri Lanka Youth, Challenges and Responses. Friedrich Ebert Stiftung.

Hymer, S., and Resnick, S. (1969). A model of an agrarian economy with nonagricultural activities. The American economic review, 59(4), 493-506.

Katz, E., and Stark, O. (1986). Labor migration and risk aversion in less developed countries. Journal of labor Economics, 4(1), 134-149.

Khatun, D., and Roy, B. C. (2012). Rural livelihood diversification in West Bengal: determinants and constraints. Agricultural Economics Research Review, 25(347-2016-16910), 115-124.

Kottegoda, S. (2004). Poverty, Migration and Family: the Politics of Gender in Sri Lanka. 
Krugman, P. and Wells, R. (2015). Economics. 4th ed. New York, NY: Worth Publishers, pp.282-284.

Lewis, W. A. (1954). Economic development with unlimited supplies of labour. The manchester school, 22(2), 139-191.

Lipton, M., and Ravallion, M. (1995). Poverty and policy. Handbook of development economics, 3, 2551-2657.

Mankiw, N. G. (2014). Essentials of economics. Cengage learning.

Mapa, R. B., Kumaragamage, D., Gunarathne, W. D. L., and Dassanayake, A. R. (2002). Land use in Sri Lanka: past, present and the future. In 17th World Congress of Social Science (WCSS), Thailand.

Marambe, B., Silva, P., and Athauda, S. (2017). Agriculture and Rural Development Under Central Government and Provincial Council Setup in Sri Lanka. In Decentralization and Development of Sri Lanka Within a Unitary State (pp. 111-145). Springer, Singapore.

Marzano, M. (2002). Rural livelihoods in Sri Lanka: an indication of poverty?. Journal of International Development, 14(6), 817-828.

Meredith Lewis (2007). An IntroductIon to HousIng And land laws in Sri Lanka. [online] Colombo: Wits Associates (Pvt) Ltd., pp.52-96. Available at: http://www.cepa.lk/content_images/publications/documents/213-S-COHREAn\%20intro.\%20to\%20housing\%20and\%20land\%20laws\%20in\%20SL.pdf [Accessed 6 Jan. 2019].

Ministry of Youth Affairs and Skills Development (2014). National Youth Policy Sri Lanka. Colombo: Democratic Socialist Republic of Sri Lanka.

Morrison, B. M. (1980). Rural household livelihood strategies in a Sri Lankan village. The Journal of Development Studies, 16(4), 443-462.

Nakajima, C. (2012). Subjective equilibrium theory of the farm household (Vol. 3). Elsevier.

Nakajima, C. (2017). Subsistence and commercial family farms: some theoretical models of subjective equilibrium. In Subsistence agriculture and economic development (pp. 165-184). Routledge.

Ogawa, R., Chan, R. K., Oishi, A. S., and Wang, L. R. (Eds.). (2018). Gender, care and migration in East Asia. Springer Singapore.

Palriwala, R., and Uberoi, P. (Eds.). (2008). Marriage, migration and gender (Vol. 5). SAGE Publications Ltd.

Quan, J. (2006). Land access in the 21 st century. 
Singh. I (1986). Agricultural household models (No. 331.763 Si643a Ej. 1 002480). The Johns Hopkins University Press,

SLBFE. (2006). Annual Statistical Report of Foreign Employment - 2006. In SLBFE. SLBFE.

SLBFE. (2017). Annual Statistical Report of Foreign Employment 2017. In slbfe.lk. Retrieved from SLBFE website: http://www.slbfe.lk/file.php?FID=487 [Accessed 10 Oct. 2018].

Stark, D. (1980). Class struggle and the transformation of the labor process. Theory and Society, 9(1), 89-130.

Stark, O., and Bloom, D. E. (1985). The new economics of labor migration. The american Economic review, 75(2), 173-178.

Stark, O., and Levhari, D. (1982). On migration and risk in LDCs. Economic development and cultural change, 31(1), 191-196.

Stark, O., and Lucas, R. E. (1988). Migration, remittances, and the family. Economic development and cultural change, 36(3), 465-481.

Todaro, M. P. (1969). A model of labor migration and urban unemployment in less developed countries. The American economic review, 59(1), 138-148.

Todaro, M. P. (1997). Economic Development 6th Edition, New York zeller M and Sharma. 2001. Group Based Financial Institution in the rural poor in Bangladesh, an institutional and Hose hold level analysis. Research report. 20, Washington DC.

Todaro, M. P., and Smith, S. C. (2015). Economic development (12th ed.). Uttar Pradesh, India: Pearson India Education Services.

Vodopivec, M., and Arunatilake, N. K. (2008). The impact of population aging on the labor market: The case of Sri Lanka. Available at SSRN 1136177.

Vodopivec, M., Gunatlilaka, R., and Mayer, M. (2010). The Challenge of Youth Unemployment in Sril Lanka.

Vries, W. M. D. (1993). Farming with other gainful activities in the Netherlands. Sociologia Ruralis, 33(2), 190-202.

Walker, J., and Ben-Akiva, M. (2002). Generalized random utility model. Mathematical social sciences, 43(3), 303-343.

Weerahewa, J., Kodithuwakku, S. S., and Udayanganie, D. (2004). IS AGRICULTURAL DIVERSIFICATION AViable STRATEGY FOR IMPROVING RURAL WELL-BEING IN SRI LANKA?. 
World Bank. (2018a). Arable land (\% of land area) - Sri Lanka | Data. Retrieved November 25, 2018, from Worldbank.org website: https://data.worldbank.org/indicator/AG.LND.ARBL.ZS?locations=LK\&view= chart

World Bank. (2018b). Unemployment, youth total (\% of total labor force ages 15-24) (modeled ILO estimate) | Data. Retrieved April 1, 2019, from Worldbank.org website: https://data.worldbank.org/indicator/SL.UEM.1524.ZS 